\title{
Review Article \\ Xanthine Oxidase: Isolation, Assays of Activity, and Inhibition
}

\author{
Danijela A. Kostić, Danica S. Dimitrijević, Gordana S. Stojanović, Ivan R. Palić, \\ Aleksandra S. Đorđević, and Jovana D. Ickovski
}

Department of Chemistry, Faculty of Science and Mathematics, University of Nis, Visegradska 33, 18000 Nis, Serbia

Correspondence should be addressed to Danica S. Dimitrijević; danicadimitrijevic7@gmail.com

Received 18 November 2014; Accepted 21 January 2015

Academic Editor: Patricia Valentao

\begin{abstract}
Copyright (C) 2015 Danijela A. Kostić et al. This is an open access article distributed under the Creative Commons Attribution License, which permits unrestricted use, distribution, and reproduction in any medium, provided the original work is properly cited.

Xanthine oxidase $(\mathrm{XO})$ is an important enzyme catalyzing the hydroxylation of hypoxanthine to xanthine and xanthine to uric acid which is excreted by kidneys. Excessive production and/or inadequate excretion of uric acid results in hyperuricemia. This paper presents a detailed review of methods of isolation, determination of xanthine oxidase activity, and the effect of plant extracts and their constituents on it. Determining the content and activities of XO can be used for diagnostic purposes. Testing inhibition of XO is important for detection of potentially effective compounds or extracts that can be used to treat diseases that are caused by increased activity of XO. In vitro bioassays are used to examine test material for XO inhibition, as inhibitors of XO may be potentially useful for the treatment of gout or other XO induced diseases. Several authors reported on the XO inhibitory potential of traditionally used medicinal plants.
\end{abstract}

\section{Introduction}

Reactive oxygen species (ROS) such as hydrogen peroxide, superoxide radical anion, hydroxyl radical, alkylperoxyl radical, nitric oxide, and singlet oxygen are often associated with some physiopathological states in human. Oxidative stress, caused by an imbalance between antioxidant systems and the production of oxidants, including ROS, is considered to contribute to a wide variety of degenerative processes and diseases such as atherosclerosis, Parkinson's disease, Alzheimer's dementia, and reperfusion injury of brain or heart $[1,2]$ and also can be associated with the pathogenesis of various conditions such as aging, arthritis, cancer, and inflammation $[2,3]$. ROS are generated inside the human body as a consequence of the exposure to a multitude of exogenous chemicals in our ambient environment like during UV light irradiation and by X-rays and gamma rays or produced during metal catalyzed reactions [4] and/or a number of endogenous metabolic processes involving redox enzymes and bioenergetics electron transfer [5]. Endogenous factors leading to formation of ROS can be neutrophils and macrophages during inflammation or byproducts of mitochondrial catalyzed electron transport reactions and various other mechanisms [6]. Endogenous sources of ROS include mitochondria, cytochrome P450 metabolism, peroxisomes, and inflammatory cell activation [7], so as other cellular sources of superoxide radicals present such as the enzyme xanthine oxidase, which catalyzes the reaction of hypoxanthine to xanthine and xanthine to uric acid. In both steps, molecular oxygen is reduced, forming the superoxide anion followed by the generation of hydrogen peroxide [8].

Besides these, many studies have now confirmed that exogenic antioxidants, especially supplied by foods, are essential for counteracting oxidative stress. These antioxidants mainly come from plants in the form of phenolic compounds (flavonoids, phenolic acids and alcohols, stilbenes, tocopherols, and tocotrienols) [9]. Many studies have suggested that flavonoids exhibit biological activities, including antiallergenic, antiviral, anti-inflammatory, and vasodilating actions. These pharmacological effects are linked to the antioxidant properties of flavonoids. Protective effects of flavonoids are ascribed to their capacity to suppress ROS formation by inhibiting some enzymes or chelating trace elements involved in free radical production, scavenge radical species and more specially the ROS, and improve regulation antioxidant defense [10-13].

The aim of this study is to give an overview of methods for isolation and determination of $\mathrm{XO}$ activity. 


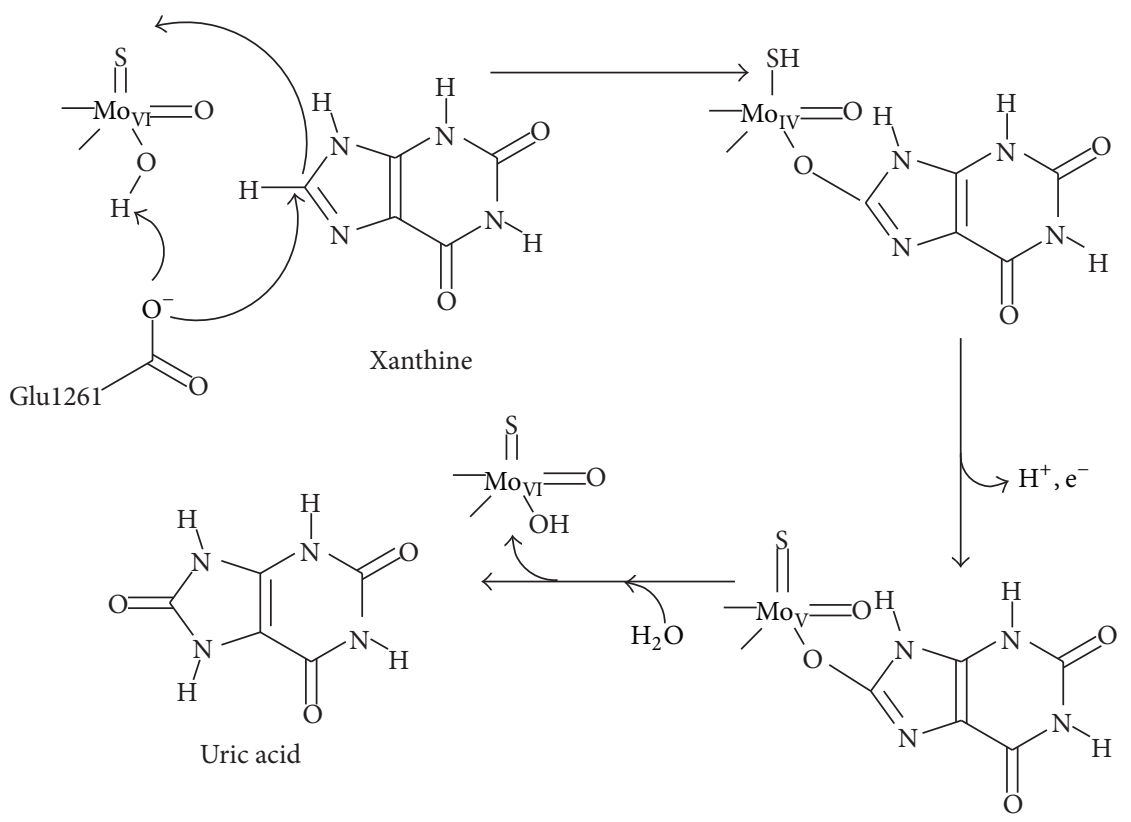

SCHeme 1: Transformation of xanthine to uric acid by XO.<smiles>O=c1[nH]cnc2[nH]cnc12</smiles><smiles>O=c1[nH]c(=O)c2nc[nH]c2[nH]1</smiles><smiles></smiles><smiles></smiles>
Allopurinol<smiles>[14CH3]n1c(=O)[nH]c(=O)c2[nH]c(=O)[nH]c21</smiles>

FIGURE 1: Inhibition of xanthine oxidase by allopurinol to prevent conversion of hypoxanthine to xanthine and/or uric acid.

\section{Xanthine Oxidase: Mechanism of Action}

In 1902, Schardinger [14] showed that milk contains an enzyme capable of oxidizing aldehydes to acids, accompanied by the reduction of methylene blue; this enzyme was then commonly called the "Schardinger enzyme." In 1922, Morgan et al. [15] showed that milk contains an enzyme capable of oxidizing xanthine and hypoxanthine, with the concomitant reduction of $\mathrm{O}_{2}$ to $\mathrm{H}_{2} \mathrm{O}_{2}$, and this enzyme was called XO. Hass and Hill [16] and Hass and Lee [17] reported that milk contains a substance, which they called "itate," capable of oxidizing nitrite to nitrate in the presence of an aldehyde and $\mathrm{O}_{2}$ under other conditions, and that milk could reduce nitrate to nitrite. In 7 1938, Booth [18] presented strong evidence that the Schardinger enzyme was, in fact, XO.

$\mathrm{XO}$ is a homodimer with molecule mass of $290 \mathrm{kDa}$. Xanthine oxidase belongs to the molybdenum-protein family containing one molybdenum, one of the flavin adenine dinucleotides (FAD), and two iron-sulfur (2Fe-2S) centers of the ferredoxin type in each of its two independent subunits. The enzyme contains two separated substrate-binding sites. $\mathrm{XO}$ catalysed the oxidation of hypoxanthine to xanthine and 
TABLE 1: Assay procedure of effect of plant extract on xanthine oxidase activity.

\begin{tabular}{|c|c|c|}
\hline Reference & Tested sample & Assay procedures \\
\hline [19] & Erythrinastricta Roxb. fractions & $\begin{array}{l}\text { Sample fraction }(1 \mathrm{~mL}, 5-100 \mu \mathrm{g} / \mathrm{mL}) \text {, phosphate buffer }(\mathrm{pH} \text { 7.5) }(2.9 \mathrm{~mL}) \text {, xanthine } \\
\text { oxidase }(0.1 \mathrm{~mL}, 0.1 \mathrm{units} / \mathrm{mL} \text { in phosphate buffer }) \text {; preincubation } 15 \mathrm{~min}\left(25^{\circ} \mathrm{C}\right) \text {; } \\
\text { substrate solution }(2 \mathrm{~mL}, 150 \mu \mathrm{M} \text { xanthine in buffer }) \text {; incubation } 30 \mathrm{~min}\left(25^{\circ} \mathrm{C}\right) \text {; HCl } \\
(1 \mathrm{~mL}, 1 \mathrm{M})\end{array}$ \\
\hline$[20]$ & $\begin{array}{l}\text { Lanostanoids from Ganoderma } \\
\text { tsugae }\end{array}$ & $\begin{array}{l}\text { Test solution, } 70 \mathrm{mM} \text { phosphate buffer ( } \mathrm{pH} 7.5) \text {; enzyme solution }(0.1 \text { units } / \mathrm{mL} \text { in } \\
70 \mathrm{mM} \text { phosphate buffer }(\mathrm{pH} 7.5)) \text {; preincubation } 25^{\circ} \mathrm{C} \text { for } 15 \mathrm{~min} \text {; substrate } \\
(150 \mu \mathrm{M} \text { xanthine in the same buffer) }\end{array}$ \\
\hline$[21]$ & Food extracts and components & $\begin{array}{l}\text { Test sample, xanthine }(0.8 \mathrm{~mL}, 150 \mu \mathrm{M}) \text {, hydroxylamine }(0.2 \mathrm{mM}) \text {, and EDTA } \\
(0.1 \mathrm{mM}) \text {, all in sodium phosphate buffer }(0.2 \mathrm{M}, \mathrm{pH} \text { 7.5); XO }(0.2 \mathrm{~mL}, 23.42 \mathrm{mili} \text {, } \\
0.2 \mathrm{M} \text { phosphate buffer }) \text {; incubation } 30 \mathrm{~min}\left(37^{\circ} \mathrm{C}\right) ; \mathrm{HCl}(0.1 \mathrm{~mL}, 5 \mathrm{M})\end{array}$ \\
\hline$[22]$ & Malaysian medicinal plant & $\begin{array}{l}\text { Sodium phosphate buffer (pH } 7.5)(300 \mu \mathrm{L}, 50 \mathrm{mM}), 100 \mu \mathrm{L} \text { of sample solution in } \\
\text { distilled water or DMSO, enzyme solution }(100 \mu \mathrm{L}, 0.2 \text { units } / \mathrm{mL} \text { of xanthine } \\
\text { oxidase in phosphate buffer), } 100 \mu \mathrm{L} \text { of distilled water; preincubation } 15 \min \left(37^{\circ} \mathrm{C}\right) \text {; } \\
\text { xanthine }(200 \mu \mathrm{L}, 0.15 \mathrm{mM}) \text {; incubation } 30 \min \left(37^{\circ} \mathrm{C}\right) ; 200 \mu \mathrm{L} \text { of } 0.5 \mathrm{M} \mathrm{HCl}\end{array}$ \\
\hline$[23]$ & $\begin{array}{l}\text { Edible plants of the Turkmen } \\
\text { Sahra region }\end{array}$ & $\begin{array}{l}\text { Plant extract }(0.250 \mathrm{~mL} \text { in } 50 \mathrm{mM} \text { potassium phosphate buffer, } \mathrm{pH}=7.4) \text {, xanthine } \\
(0.330 \mathrm{~mL}, 0.15 \mathrm{mM}) \text {, potassium phosphate buffer }(\mathrm{pH} 7.4)(0.385 \mathrm{~mL}, 50 \mathrm{mM}) ; \mathrm{XO} \\
(0.035 \mathrm{~mL} \text {, in } 50 \mathrm{mM} \text { potassium phosphate buffer })\end{array}$ \\
\hline$[24]$ & Anacardic acid & $\begin{array}{l}\text { Sodium carbonate buffer containing } 0.1 \mathrm{mM} \text { EDTA (pH 10.0) }(2.76 \mathrm{~mL}, 40 \mathrm{mM}) \text {, } \\
\text { xanthine }(0.06 \mathrm{~mL}, 10 \mathrm{mM}) \text {, sample }(0.06 \mathrm{~mL} \text { in DMSO); xanthine oxidase }(0.12 \mathrm{~mL} \text {, } \\
0.04 \text { units) }\end{array}$ \\
\hline [25] & Czech medicinal plants & $\begin{array}{l}\text { Phosphate buffer (pH 7.5) }(400 \mu \mathrm{L}, 120 \mathrm{mmol} / \mathrm{L}) \text {, xanthine }(\mathrm{pH} 7.5)(330 \mu \mathrm{L} \text {, } \\
150 \mu \mathrm{mol} / \mathrm{L}) \text {, extract stock solution }(250 \mu \mathrm{L}) \text {, enzyme solution }(20 \mu \mathrm{L} 0.5 \text { units } / \mathrm{mL} \\
\text { in buffer) }\end{array}$ \\
\hline$[26]$ & Centaurium erythraea infusion & $\begin{array}{l}\text { Xanthine }(44 \mu \mathrm{M} \text { in } 1 \mu \mathrm{M} \mathrm{NaOH}), \mathrm{XO}(0.29 \mathrm{units} / \mathrm{mL} \text { in } 0.1 \mathrm{M} \text { EDTA), lyophilized } \\
\text { infusion }(5.2,10.4,20.8,41.7,83.3 \text {, and } 166.7 \mu \mathrm{g} / \mathrm{mL})\end{array}$ \\
\hline [27] & Dried S. anacardiumseeds & $0.1 \mathrm{U} / \mathrm{mL} \mathrm{XO}, 0.2 \mathrm{~mL}$ xanthine $(0.26 \mathrm{M})$ in $50 \mathrm{mM}$ phosphate buffer $(\mathrm{pH}=7.4)$ \\
\hline
\end{tabular}

subsequently to uric acid [32-34]. During the reoxidation of $\mathrm{XO}$, molecular oxygen acts as electron acceptor, producing superoxide radical and hydrogen peroxide [35]. During these reactions, superoxide anion radicals $\left(\mathrm{O}_{2}{ }^{--}\right)$and $\mathrm{H}_{2} \mathrm{O}_{2}$ are formed [35]. Superoxide anion radicals spontaneously or under the influence of enzyme superoxide dismutase (SOD) transformed into hydrogen peroxide and oxygen. These reactions can be written as follows [36] and on Scheme 1:

$$
\begin{gathered}
\text { hypoxanthine }+\mathrm{O}_{2}+\mathrm{H}_{2} \mathrm{O} \longrightarrow \text { xanthine }+\mathrm{H}_{2} \mathrm{O}_{2} \\
\text { xanthine }+2 \mathrm{O}_{2}+\mathrm{H}_{2} \mathrm{O} \longrightarrow \text { uric acid }+2 \mathrm{O}_{2}^{\cdot-}+2 \mathrm{H}^{+} \\
\text {xanthine }+\mathrm{O}_{2}+\mathrm{H}_{2} \mathrm{O} \longrightarrow \text { uric acid }+\mathrm{H}_{2} \mathrm{O}_{2} \\
2 \mathrm{O}_{2}^{\cdot-}+2 \mathrm{H}^{+} \longrightarrow \mathrm{H}_{2} \mathrm{O}_{2}+\mathrm{O}_{2}
\end{gathered}
$$

Uric acid is breakdown product of ingested and endogenously synthesized purines. DNA and RNA are degraded into purine nucleotides and bases, which are then metabolized, via the action of xanthine oxidase, to xanthine and uric acid. These later steps are irreversible and generate superoxide anions. Uric acid undergoes no further metabolism in humans and is excreted by the kidneys and intestinal tract [37].

According to this higher concentrations of uric acid may be response to the higher levels of xanthine oxidase activity and to the oxidative stress, which is characteristic for many vascular disease states [38]. The overactivity of $\mathrm{XO}$ results in a condition known as gout [39], a common rheumatic disease and an acute inflammatory arthritis [40]. The treatment for hyperuricemia and gout is either increasing the excretion of uric acid or reducing the uric acid production.

Xanthine oxidase inhibitors (XOI) are very useful for this [19]. The inhibition of XO reduces both vascular oxidative stress and circulating levels of uric acid. The inhibition of XO by allopurinol is showed in Figure 1 .

Thus, XO inhibitors may be useful for treatment of many other diseases [41, 42]. Among the many known XO inhibitors, allopurinol, oxypurinol, and febuxostat have been used widely for the treatment of hyperuricemia and gout [43]. XO inhibitors can act either at the purine binding site such as allopurinol $[44,45]$ or at the FAD cofactor site such as benzimidazole [46]. XO inhibitors act by blocking the biosynthesis of uric acid from purine in the body [47] and it is believed that either increasing the excretion of uric acid or reducing the uric acid production helps to reduce the risk of gout [48].

\section{Isolation and Purification of XO}

Isolation of $\mathrm{XO}$, as the widespread enzymes among different species, involves the extraction of the enzyme from a wide range of materials (bacteria, milk, organs of different animals, etc.) and its purification from crude extract. XO is concentrated in the milk fat/lipid globule membrane (MFGM), in which it is the second most abundant protein, after butyrophilin. Therefore, all isolation methods use cream as 
TABLE 2: Plant extract and pure compounds as potent XOI.

\begin{tabular}{|c|c|c|c|}
\hline Reference & Plant & Extract or compound & $\begin{array}{l}\text { Inhibition effect } \mathrm{IC}_{50} \text { or } \% \text { of } \\
\text { inhibition }\end{array}$ \\
\hline$[28]$ & Semecarpus anacardium & $\begin{array}{l}\text { Fractionated methanolic extract by hexane, ethyl acetate, and } \\
\text { butanol } \\
\text { Isolated compound: tetrahydroamentoflavone (THA) }\end{array}$ & $\begin{array}{l}\text { THA } \\
\text { IC }_{50} 100 \mathrm{nM}\end{array}$ \\
\hline [29] & Ajuga iva L. & $\begin{array}{l}\text { Crude } 85 \% \text { methanol extract fractionated by chloroform } \\
\text { (CE), ethyl acetate (EAE), and water (AE) }\end{array}$ & $\begin{array}{l}\mathrm{IC}_{50} 3.878-5835 \\
\mu \mathrm{M} / \text { quercetin equivalent }(\mathrm{QE})\end{array}$ \\
\hline$[30]$ & Teucrium polium & $\begin{array}{l}\text { Methanol (ME), chloroform (CE), and ethyl acetate (EAE) } \\
\text { crude extracts }\end{array}$ & $\begin{array}{l}\text { CE } 0.79, \mathrm{ME} 10.59, \mathrm{EAE} \\
11.75 \mu \mathrm{M} / \mathrm{QE}\end{array}$ \\
\hline [21] & Food extracts & Various extracts and compounds & $\begin{array}{l}\text { Hesperetin } 35 \mu \mathrm{M} / \mathrm{QE} \\
\text { Theaflavin-3,3'-digallate } \\
49 \mu \mathrm{M} / \mathrm{QE} \\
\text { Cranberry juice, purple grape } \\
\text { juice, and black tea } \\
\mathrm{IC}_{50} 2.4-5.8 \% \text { of extracts } \\
\text { Sage, cinnamon, thyme, and } \\
\text { rosemary infusions } \mathrm{IC}_{50} \\
12.9-20.4 \% \text { of infusion }\end{array}$ \\
\hline$[31]$ & Flavonoids & Genistein, apigenin, quercetin, rutin, and astilbin & $\begin{array}{l}\text { In vitro: no significant inhibitory } \\
\text { effect } \\
\text { In vivo: quercetin, rutin, and } \\
\text { astilbin-potent XOI }\end{array}$ \\
\hline
\end{tabular}

CE isolated compounds: new lanostanoids: sugaric acids A, $\mathrm{B}$, and $\mathrm{C}$, tsugarioside $\mathrm{A}$, and four known compounds, $3 \beta$-hydroxy- $5 \alpha$-lanosta-8,24-dien-21-oic acid, 3-oxo- $5 \alpha$-lanosta-8,24-dien-21-oic acid,

[20] Ganoderma tsugae Murr. ergosta-7,22-dien-3 $\beta$-ol, and (Polyporaceae) 2 $2 \beta, 3 \alpha, 9 \alpha$-trihydroxy- $5 \alpha$-ergosta-7,22-diene Potent XOI ME: two new lanostanoids, sugariosides $B$ and $C$, and a mixture of the already known compounds $5 \alpha, 8 \alpha$-epidioxyergosta- 6,22 -dien- $3 \beta$-ol and $5 \alpha, 8 \alpha$-epidioxyergosta-6,9(11),22-trien- $3 \beta$-ol Republic
Plant species from Czech
Different crude plant extracts

\author{
Methylene chloride, ME of \\ Populus nigra and Betula \\ pendula, with $\mathrm{IC}_{50}$ of 8.3 and \\ $25.9 \mu \mathrm{g} / \mathrm{mL}$, \\ $80 \%$ EE of Caryophyllus \\ aromaticus and Hypericum \\ perforatum, $50 \mu \mathrm{g} / \mathrm{mL}$ \\ Chloroform fraction $\left(\mathrm{IC}_{50} 21.2 \pm\right.$ \\ $1.6 \mu \mathrm{g} / \mathrm{mL})$, \\ pet. ether $\left(\mathrm{IC}_{50} 30.2 \pm\right.$ \\ $2.2 \mu \mathrm{g} / \mathrm{mL})$, \\ ethyl acetate $\left(\mathrm{IC}_{50} 44.9 \pm\right.$ \\ $1.4 \mu \mathrm{g} / \mathrm{mL})$, \\ and residual fraction $\left(\mathrm{IC}_{50} 100 \pm\right.$
}

Erythrina stricta

[19] (Papilionaceae) distributed in India, China, Thailand, Fractions of the hydromethanolic extract of leaves and Vietnam $3.3 \mu \mathrm{g} / \mathrm{mL})$

\section{C. erythraea flowering tops infusion}

$\begin{array}{cl}\text { Centaurium erythraea } & \begin{array}{l}\text { C. erythraea flowering tops infusion } \\ \text { (Gentianaceae) }\end{array} \\ & \begin{array}{l}\text { Identified compound: several esters of hydroxycinnamic } \\ \text { acids, namely, } p \text {-coumaric, ferulic, and sinapic acids }\end{array}\end{array}$

Noncompetitively inhibiting xanthine oxidase the starting material; the cream is washed and churned to yield a crude MFGM preparation, dissociating and reducing agents are used to liberate XO from membrane lipoproteins, and some form of chromatography is used for purification [49].

Since the discovery of XO many authors tried to purify and characterize this enzyme. Schardinger [14] is a partially purified $\mathrm{XO}$ and found that reduced activity of the enzyme is not only a consequence of the removal of fat from milk, but also to reduce the concentration of the enzyme on the surface due to the absorption of fat molecules. XO from milk was highly purified by Ball in 1939 [50]. He used continuous steps of centrifugation on milk in order to separate cream layer rich in XO. Ball [50] separated XO from cream. Since then, 
$\mathrm{XO}$ has been isolated and purified by several authors $[51,52]$. Hart and coworkers [53] prepared XO from milk according to the procedure described earlier by Palmer et al. [54]. They separated cream from milk and then added salicylate and EDTA as concentrated solutions to the cream.

The published purification procedures for xanthine oxidase include proteolytic cleavage, calcium chloride treatment, several ammonium sulfate fractionations, dialysis, and several chromatographic steps $[55,56]$. Özer et al. [57] isolated $\mathrm{XO}$ from fresh bovine milk modifying previous purification procedures to achieve high-yield purification procedure. They added EDTA and toluene in fresh milk, and after the milk was churned and cooled, the $\left(\mathrm{NH}_{4}\right)_{2} \mathrm{SO}_{4}$ was added. The suspension was centrifuged and the precipitate formed was discarded. The supernatant was brought to $50 \%$ saturation with solid ammonium sulfate.

Baghiani et al. [29] purified XO from mammalian milk (bovine), in the presence of $10 \mathrm{mM}$ of dithiothreitol, by ammonium sulphate fractionation, followed by affinity chromatography on heparin agarose.

Zhang et al. [58] isolated and purified $\mathrm{XO}$ from Arthrobacter M3. The Arthrobacter M3 culture was transferred into induction medium. The cells were harvested by centrifugation and were resuspended in sodium phosphate.

\section{XO Activity Assay: Medicinal Importance}

Determining the content and activities of XO can be used for diagnostic purposes. The most frequently used method for the determination of XO activity is described by Marcocci et al. [59] and Cos et al. [34]. The measurement is carried out in buffer $\mathrm{pH}$ 7.4, which is the most common carbonate or phosphate puffer, at 25 or $37^{\circ} \mathrm{C}$. The incubation period is made by various authors from 15 to $30 \mathrm{~min}$. EDTA is often added to complexation of metals present in the test sample. Spectrophotometric determination of XO activity is based on measuring uric acid production from xanthine or hypoxanthine substrate at around $295 \mathrm{~nm}$. The assay mixture always contains xanthine as a substrate and sample. Reaction is initiated by adding the XO. Higher values indicate a pathological condition.

Some studies support the hypothesis that uric acid is connected with elevated vascular events in patients with hypertension, diabetes, and known cardiovascular disease [60-63]. The treatment for hyperuricemia and gout is either increasing the excretion of uric acid or reducing the uric acid production. Xanthine oxidase inhibitors (XOI) are very useful for this [19]. The inhibition of XO reduces both vascular oxidative stress and circulating levels of uric acid. Allopurinol is XOI with high potential. Inhibitory activities of plant extracts and their constituents are compared with the activity of allopurinol as standard. In Table 1 is given the assay procedure of effect of plant extract on xanthine oxidase activity.

Xanthine oxidase inhibitors (XOI) are typically used in the treatment of nephropathy and renal stone diseases linked to hyperuricemia. There has been recent interest in the potential benefit of XOI in the prevention of vascular
TABLE 3: $\mathrm{IC}_{50}$ values of flavonoids and allopurinol for inhibition of $\mathrm{XO}$.

\begin{tabular}{lc}
\hline Compounds & $\mathrm{XO} \mathrm{IC}_{50}(\mu \mathrm{M}) \pm \mathrm{SD}$ \\
\hline ( \pm -Taxifolin & $>100$ \\
$(+)$-Catechin & $>100$ \\
$(-)$-Epicatechin & $>100$ \\
$(-)$-Epigallocatechin & $>100$ \\
$4^{\prime}$-Hydroxyflavanone & $>30$ \\
Naringenin & $>50$ \\
7-Hydroxyflavanone & $38.0 \pm 7.0$ \\
Chrysin & $0.84 \pm 0.13$ \\
Apigenin & $0.70 \pm 0.23$ \\
Luteolin & $0.55 \pm 0.04$ \\
Baicalein & $2.79 \pm 0.01$ \\
3-Hydroxyflavone & $>100$ \\
Galangin & $1.80 \pm 0.07$ \\
Kaempferol & $1.06 \pm 0.03$ \\
Quercetin & $2.62 \pm 0.13$ \\
Fisetin & $4.33 \pm 0.19$ \\
Morin & $10.1 \pm 0.70$ \\
Myricetin & $2.38 \pm 0.13$ \\
Allopurinol & $0.24 \pm 0.01$ \\
Luteolin + epigallocatechin $(1: 1)$ & $0.76 \pm 0.08$ \\
\hline
\end{tabular}

disease, because of emerging evidence suggesting a role for serum uric acid in the development of cardiovascular disease; the enzyme is an important source of oxidative stress in the vasculature [64]. XOI are agents that directly inhibit the synthesis of uric acid in vivo. Certain active constituents present in crude plant extracts like flavonoids and polyphenolic compounds have been reported to possess XOI $[65,66]$. These findings have opened the possibility of isolation of new natural compounds, which can be possible inhibitors of $\mathrm{XO}$, and led to the growing interest in the investigation of medicinal plants. The activity of flavonoids as inhibitors of xanthine oxidase in vitro has been reported. The absence of a hydroxyl group at C-3 enhances slightly the inhibition effect on XO [34, 67, 68].

In traditional medicine are used many herbs and their extracts in the treatment of various diseases that are the result of increased XO activity. Scientists have studied why some plants and their extracts have an inhibitory effect on the activity of XO (Table 3) [69].

In Table 2 are given plant extract and pure compounds as potent XOI.

The structure-activity relationship of flavonoids as inhibitors of xanthine oxidase and as scavengers of the superoxide radical, produced by the action of the enzyme xanthine oxidase, was investigated. The hydroxyl groups at C-5 and C-7 and the double bond between C- 2 and C- 3 were essential for a high inhibitory activity on xanthine oxidase. Flavones showed slightly higher inhibitory activity than flavonols [34]. 


\section{Conclusions}

This review is an overview of methods for the isolation and determination of $\mathrm{XO}$ activity in vivo and in vitro and inhibition by plant extracts and their constituents. For isolation the most used methods are extraction, centrifugation, and chromatographic separation. Plant extracts and their constituents show good inhibitor activity and therefore may have a positive impact on the prevention of disease caused by increased activity of XO. Elevated concentrations of uric acid in the blood stream of human body lead to formation of gout, characterized by hyperuricemia and recurrent attacks of arthritis, so xanthine oxidase (XO) inhibitors may serve as therapeutic agents for hyperuricemia and/or gout. Xanthine oxidase inhibitors are agents that directly inhibit the synthesis of uric acid in vivo. Certain active constituents present in crude plant extracts like flavonoids and polyphenolic compounds have been reported to possess XOI. These findings have opened the possibility of isolation of new natural compounds, which can be potent inhibitors of $\mathrm{XO}$, and led to the growing interest in the investigation of medicinal plants.

\section{Conflict of Interests}

The authors declare that there is no conflict of interests regarding the publication of this paper.

\section{Acknowledgment}

Financial support of this work is provided by the Serbian Ministry of Education and Science, Project no. ON 172047.

\section{References}

[1] K. Sachidanandam, S. C. Fagan, and A. Ergul, "Oxidative stress and cardiovascular disease: antioxidants and unresolved issues," Cardiovascular Drug Reviews, vol. 23, no. 2, pp. 115-132, 2005.

[2] B. Halliwell and J. M. C. Gutteridge, "Free radicals, ageing and disease," in Free Radicals in Biology and Medicine, pp. 422-437, Clarendron Press, Oxford, UK, 1989.

[3] U. Gawlik-Dziki, M. Świeca, D. Sugier, and J. Cichocka, "Comparison of in vitro lipoxygenase, xanthine oxidase inhibitory and antioxidant activity of Arnica montana and Arnica chamissonis tinctures," Acta Scientiarum Polonorum, Hortorum Cultus, vol. 10, no. 3, pp. 15-27, 2011.

[4] E. Cadenas, "Biochemistry of oxygen toxicity," Annual Review of Biochemistry, vol. 58, pp. 79-110, 1989.

[5] G.-R. Zhao, Z.-J. Xiang, T.-X. Ye, Y.-J. Yuan, and Z.-X. Guo, "Antioxidant activities of Salvia miltiorrhiza and Panax notoginseng," Food Chemistry, vol. 99, no. 4, pp. 767-774, 2006.

[6] E. Cadenas and K. J. A. Davies, "Mitochondrial free radical generation, oxidative stress, and aging," Free Radical Biology and Medicine, vol. 29, no. 3-4, pp. 222-230, 2000.

[7] M. Inoue, E. F. Sato, M. Nishikawa et al., "Mitochondrial generation of reactive oxygen species and its role in aerobic life," Current Medicinal Chemistry, vol. 10, no. 23, pp. 2495-2505, 2003.

[8] M. Valko, M. Izakovic, M. Mazur, C. J. Rhodes, and J. Telser, "Role of oxygen radicals in DNA damage and cancer incidence,"
Molecular and Cellular Biochemistry, vol. 266, no. 1-2, pp. 37-56, 2004.

[9] M. Laguerre, J. Lecomte, and P. Villeneuve, "Evaluation of the ability of antioxidants to counteract lipid oxidation: existing methods, new trends and challenges," Progress in Lipid Research, vol. 46, no. 5, pp. 244-282, 2007.

[10] M. Ferrali, C. Signorini, B. Caciotti et al., "Protection against oxidative damage of erythrocyte membrane by the flavonoid quercetin and its relation to iron chelating activity," FEBS Letters, vol. 416, no. 2, pp. 123-129, 1997.

[11] A. J. Elliott, S. A. Scheiber, C. Thomas, and R. S. Pardini, "Inhibition of glutathione reductase by flavonoids. A structureactivity study," Biochemical Pharmacology, vol. 44, no. 8, pp. 1603-1608, 1992.

[12] R. Hirano, W. Sasamoto, A. Matsumoto, H. Itakura, O. Igarashi, and K. Kondo, "Antioxidant ability of various flavonoids against DPPH radicals and LDL oxidation," Journal of Nutritional Science and Vitaminology, vol. 47, no. 5, pp. 357-362, 2001.

[13] N. Cotelle, J.-L. Bernier, J.-P. Catteau, J. Pommery, J.-C. Wallet, and E. M. Gaydou, "Antioxidant properties of hydroxyflavones," Free Radical Biology and Medicine, vol. 20, no. 1, pp. 35-43, 1996.

[14] F. Schardinger, "Ueber das Verhalten der Kuhmilchgegen Methylenblau und seine Verwendungzur Unterscheidung von ungekochterund gekochter Milch," Zeitschrift für Untersuchung der Nahrungs- und Genussmittel, vol. 5, no. 22, pp. 1113-1121, 1902.

[15] E. J. Morgan, C. P. Stewart, and F. G. Hopkins, "On the anaerobic and aerobic oxidation of xanthin and hypoxanthin by tissues and by milk," Proceedings of the Royal Society of London. Series $B$, vol. 94, no. 657, pp. 109-131, 1922.

[16] P. Hass and T. G. Hill, "Observations on certain reducing and oxidizing reactions in milk," Biochemical Journal, vol. 17, pp. 671-682, 1923.

[17] P. Hass and B. Lee, "Further observations on certain reducing and oxidizing reactions in milk," Biochemical Journal, vol. 18, pp. 614-620, 1924.

[18] V. H. Booth, “The specificity of xanthine oxidase," Biochemical Journal, vol. 32, pp. 494-502, 1938.

[19] M. Umamaheswari, K. AsokKumar, A. Somasundaram, T. Sivashanmugam, V. Subhadradevi, and T. K. Ravi, "Xanthine oxidase inhibitory activity of some Indian medical plants," Journal of Ethnopharmacology, vol. 109, no. 3, pp. 547-551, 2007.

[20] K.-W. Lin, Y.-T. Chen, S.-C. Yang, B.-L. Wei, C.-F. Hung, and C.-N. Lin, "Xanthine oxidase inhibitory lanostanoids from Ganoderma tsugae," Fitoterapia, vol. 89, no. 1, pp. 231-238, 2013.

[21] T. P. Dew, A. J. Day, and M. R. A. Morgan, "Xanthine oxidase activity in vitro: effects of food extracts and components," Journal of Agricultural and Food Chemistry, vol. 53, no. 16, pp. 6510-6515, 2005.

[22] S. M. N. Azmi, P. Jamal, and A. Amid, "Xanthine oxidase inhibitory activity from potential Malaysian medicinal plant as remedies for gout," International Food Research Journal, vol. 19, no. 1, pp. 159-165, 2012.

[23] S. M. Motamed and F. Naghibi, "Antioxidant activity of some edible plants of the Turkmen Sahra region in northern Iran," Food Chemistry, vol. 119, no. 4, pp. 1637-1642, 2010.

[24] N. Masuoka and I. Kubo, "Characterization of xanthine oxidase inhibition by anacardic acids," Biochimica et Biophysica ActaMolecular Basis of Disease, vol. 1688, no. 3, pp. 245-249, 2004. 
[25] J. Havlik, R. G. de la Huebra, K. Hejtmankova et al., "Xanthine oxidase inhibitory properties of Czech medicinal plants," Journal of Ethnopharmacology, vol. 132, no. 2, pp. 461-465, 2010.

[26] P. Valentão, E. Fernandas, F. Carvalho, P. B. Andrade, R. M. Seabra, and M. L. Bastos, "Antioxidant activity of Centaurium erythraea infusion evidenced by its superoxide radical scavenging and xanthine oxidase inhibitory activity," Journal of Agricultural and Food Chemistry, vol. 49, no. 7, pp. 3476-3479, 2001.

[27] A. Nagao, M. Seki, and H. Kobayashi, "Inhibition of xanthine oxidase by flavonoids," Bioscience, Biotechnology and Biochemistry, vol. 63, no. 10, pp. 1787-1790, 1999.

[28] S. Boumerfeg, A. Baghiani, M. Djarmouni et al., "Inhibitory Activity on xanthine oxidase and antioxidant properties of Teucrium polium L. extracts," Chinese Medicine, vol. 3, pp. 3041, 2012.

[29] A. Baghiani, S. Boumerfeg, M. Adjadj et al., "Antioxidants, free radicals scavenging and xanthine oxidase inhibitory potentials of Ajuga iva L. extracts," Free Radicals and Antioxidants, vol. 1, no. 4, pp. 21-30, 2011.

[30] J. Huang, S. Wang, M. Zhu, J. Chen, and X. Zhu, "Effects of genistein, apigenin, quercetin, rutin and astilbin on serum uric acid levels and xanthine oxidase activities in normal and hyperuricemic mice," Food and Chemical Toxicology, vol. 49, no. 9, pp. 1943-1947, 2011.

[31] Y.-T. Tung and S.-T. Chang, "Inhibition of xanthine oxidase by Acacia confusa extracts and their phytochemicals," Journal of Agricultural and Food Chemistry, vol. 58, no. 2, pp. 781-786, 2010.

[32] F. Candan, "Effect of Rhus coriaria L. (Anacardiaceae) on superoxide radical scavenging and xanthine oxidase activity," Journal of Enzyme Inhibition and Medicinal Chemistry, vol. 18, no. 1, pp. 59-62, 2003.

[33] A. Mittal, A. R. J. Phillips, B. Loveday, and J. A. Windsor, "The potential role for xanthine oxidase inhibition in major intraabdominal surgery," World Journal of Surgery, vol. 32, no. 2, pp. 288-295, 2008.

[34] P. Cos, L. Ying, M. Calomme et al., "Structure-activity relationship and classification of flavonoids as inhibitors of xanthine oxidase and superoxide scavengers," Journal of Natural Products, vol. 61, no. 1, pp. 71-76, 1998.

[35] E. E. Kelley, N. K. H. Khoo, N. J. Hundley, U. Z. Malik, B. A. Freeman, and M. M. Tarpey, "Hydrogen peroxide is the major oxidant product of xanthine oxidase," Free Radical Biology and Medicine, vol. 48, no. 4, pp. 493-498, 2010.

[36] J. Flemmig, K. Kuchta, J. Arnhold, and H. W. Rauwald, “Olea europaea leaf (Ph.Eur.) extract as well as several of its isolated phenolics inhibit the gout-related enzyme xanthine oxidase," Phytomedicine, vol. 18, no. 7, pp. 561-566, 2011.

[37] J. Dawson and M. Walters, "Uric acid and xanthine oxidase: future therapeutic targets in the prevention of cardiovascular disease?" British Journal of Clinical Pharmacology, vol. 62, no. 6, pp. 633-644, 2006.

[38] F. J. Nieto, C. Iribarren, M. D. Gross, G. W. Comstock, and R. G. Cutler, "Uric acid and serum antioxidant capacity: a reaction to atherosclerosis?" Atherosclerosis, vol. 148, no. 1, pp. 131-139, 2000.

[39] A. Burke, E. Smyth, and G. A. FitzGerald, "Analgesicantipyretic agents; pharmacotherapy of gout," in The Pharmacological Basis of Therapeutics, L. L. Brunton, J. S. Lazo, and K. L. Parker, Eds., pp. 706-710, McGraw-Hill Medical Publishing Division, New York, NY, USA, 11th edition, 2006.
[40] H. K. Choi, D. B. Mount, and A. M. Reginato, "Pathogenesis of gout, Annals of Internal Medicine, vol. 143, no. 7, pp. 499-516, 2005.

[41] M. T. T. Nguyen, S. Awale, Y. Tezuka, Q. Le Tran, and S. Kadota, "Xanthine oxidase inhibitors from the heartwood of Vietnamese Caesalpinia sappan," Chemical and Pharmaceutical Bulletin, vol. 53, no. 8, pp. 984-988, 2005.

[42] P. Higgins, L. D. Ferguson, and M. R. Walters, "Xanthine oxidase inhibition for the treatment of stroke disease: a novel therapeutic approach," Expert Review of Cardiovascular Therapy, vol. 9, no. 4, pp. 399-401, 2011.

[43] T. M. Ngoc, N. M. Khoi, D. T. Ha et al., "Xanthine oxidase inhibitory activity of constituents of Cinnamomum cassia twigs," Bioorganic and Medicinal Chemistry Letters, vol. 22, no. 14, pp. 4625-4628, 2012.

[44] R. Hille and V. Massey, "Tight binding inhibitors of xanthine oxidase," Pharmacology and Therapeutics, vol. 14, no. 2, pp. 249263, 1981.

[45] T. R. Hawkes, G. N. George, and R. C. Bray, "The structure of the inhibitory complex of alloxanthine $(1 \mathrm{H}$-pyrazolo[3,4d]pyrimidine-4,6-diol) with the molybdenum centre of xanthine oxidase from electron-paramagnetic-resonance spectroscopy," Biochemical Journal, vol. 218, no. 3, pp. 961-968, 1984.

[46] E. B. Skibo, "Noncompetitive and irreversible inhibition of xanthine oxidase by benzimidazole analogues acting at the functional flavin adenine dinucleotide cofactor," Biochemistry, vol. 25, no. 15, pp. 4189-4194, 1986.

[47] T. Unno, A. Sugimoto, and T. Kakuda, "Xanthine oxidase inhibitors from the leaves of Lagerstroemia speciosa (L.) Pers," Journal of Ethnopharmacology, vol. 93, no. 2-3, pp. 391-395, 2004.

[48] M. Umamaheswari, K. Asokkumar, A. T. Sivashanmugam, A. Remyaraju, V. Subhadradevi, and T. K. Ravi, "In vitro xanthine oxidase inhibitory activity of the fractions of Erythrina stricta Roxb.," Journal of Ethnopharmacology, vol. 124, no. 3, pp. 646648, 2009.

[49] P. F. Fox and A. L. Kelly, "Indigenous enzymes in milk: overview and historical aspects - part 1," International Dairy Journal, vol. 16, no. 6, pp. 500-516, 2006.

[50] E. G. Ball, "Xanthine oxidase, purification and properties," The Journal of Biological Chemistry, vol. 128, pp. 51-67, 1939.

[51] N. Y. Farkye, "Indigenous enzymes in milk; other enzymes," in Advanced Dairy Chemistry Volume 1: Proteins, P. F. Fox, Ed., pp. 339-367, Elsevier Applied Science, London, UK, 1992.

[52] N. Y. Farkye, "Indigenous enzymes in milk: other enzymes," in Advanced Dairy Chemistry, P. F. Fox and P. L. H. McSweeney, Eds., Elsevier, 2003.

[53] L. I. Hart, M. A. McGartoll, H. R. Chapman, and R. C. Bray, "The composition of milk xanthine oxidase," Biochemical Journal, vol. 116, no. 5, pp. 851-864, 1970.

[54] G. Palmer, R. C. Bray, and H. Beinert, "Direct studies on the electron transfer sequence in xanthine oxidase by electron paramagnetic resonance spectroscopy I. Techniques and description of spectra," The Journal of Biological Chemistry, vol. 239, pp. 2657-2666, 1964.

[55] C. A. Nelson and P. Handler, "Preparation of bovine xanthine oxidase and the subunit structures of some iron flavoproteins.," The Journal of Biological Chemistry, vol. 243, no. 20, pp. 5368$5373,1968$.

[56] W. R. Waud, F. O. Brady, R. D. Wiley, and K. V. Rajagopalan, "A new purification procedure for bovine milk xanthine oxidase: 
effect of proteolysis on the subunit structure," Archives of Biochemistry and Biophysics, vol. 169, no. 2, pp. 695-701, 1975.

[57] N. Özer, M. Müftüoglu, D. Ataman, A. Ercan, and I. H. Ögüs, "Simple, high-yield purification of xanthine oxidase from bovine milk," Journal of Biochemical and Biophysical Methods, vol. 39, no. 3, pp. 153-159, 1999.

[58] Y. Zhang, Y. Xin, H. Yang et al., "Novel affinity purification of xanthine oxidase from Arthrobacter M3," Journal of Chromatography B: Analytical Technologies in the Biomedical and Life Sciences, vol. 906, pp. 19-24, 2012.

[59] L. Marcocci, L. Packer, M.-T. Droy-Lefaix, A. Sekaki, and M. Gardes-Albert, "Antioxidant action of Ginkgo biloba extract EGb 761," Methods in Enzymology, vol. 234, pp. 462-475, 1994.

[60] J. F. Baker, E. Krishnan, L. Chen, and H. R. Schumacher, "Serum uric acid and cardiovascular disease: recent developments, and where do they leave us?" The American Journal of Medicine, vol. 118, no. 8, pp. 816-826, 2005.

[61] S. Kivity, E. Kopel, E. Maor et al., "Association of serum uric acid and cardiovascular disease in healthy adults," The American Journal of Cardiology, vol. 111, no. 8, pp. 1146-1151, 2013.

[62] S. G. Wannamethee, "Serum uric acid and risk of coronary heart disease," Current Pharmaceutical Design, vol. 11, no. 32, pp. 4125-4132, 2005.

[63] E. J. Newman, F. S. Rahman, K. R. Lees, C. J. Weir, and M. R. Walters, "Elevated serum urate concentration independently predicts poor outcome following stroke in patients with diabetes," Diabetes/Metabolism Research and Reviews, vol. 22, no. 1, pp. 79-82, 2006.

[64] P. Higgins, J. Dawson, and M. Walters, “The potential for xanthine oxidase inhibition in the prevention and treatment of cardiovascular and cerebrovascular disease," Cardiovascular Psychiatry and Neurology, vol. 2009, Article ID 282059, 9 pages, 2009.

[65] W. S. Chang, Y. J. Lee, F. J. Lu, and H. C. Chiang, "Inhibitory effects of flavonoids on xanthine oxidase," Anticancer Research, vol. 13, no. 6, pp. 2165-2170, 1993.

[66] L. Costantino, A. Albasini, G. Rastelli, and S. Benvenuti, "Activity of polyphenolic crude extracts as scavengers of superoxide radicals and inhibitors of xanthine oxidase," Planta Medica, vol. 58, no. 4, pp. 342-344, 1992.

[67] D. E. C. van Hoorn, R. J. Nijveldt, P. A. M. van Leeuwen et al., "Accurate prediction of xanthine oxidase inhibition based on the structure of flavonoids," European Journal of Pharmacology, vol. 451, no. 2, pp. 111-118, 2002.

[68] R. Arimboor, M. Rangan, S. G. Aravind, and C. Arumughan, "Tetrahydroamentoflavone (THA) from Semecarpus anacardium as a potent inhibitor of xanthine oxidase," Journal of Ethnopharmacology, vol. 133, no. 3, pp. 1117-1120, 2011.

[69] M. T. Nguyen, S. Awale, Y. Tezuka, J. Y. Ueda, Q. Tran, and S. Kadota, "Xanthine oxidase inhibitors from the flowers of Chrysanthemum sinense," Planta Medica, vol. 72, no. 1, pp. 4651, 2006. 

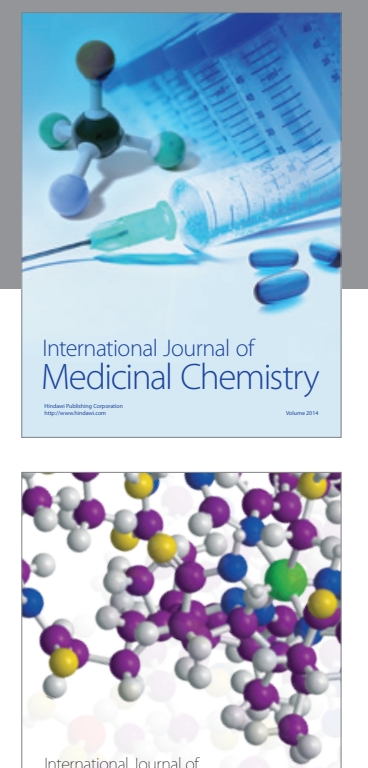

\section{Carbohydrate} Chemistry

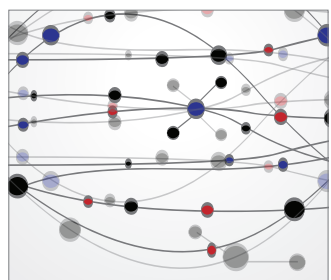

The Scientific World Journal
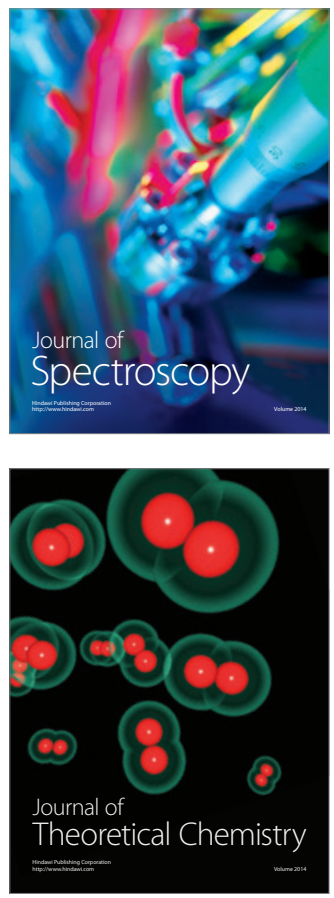
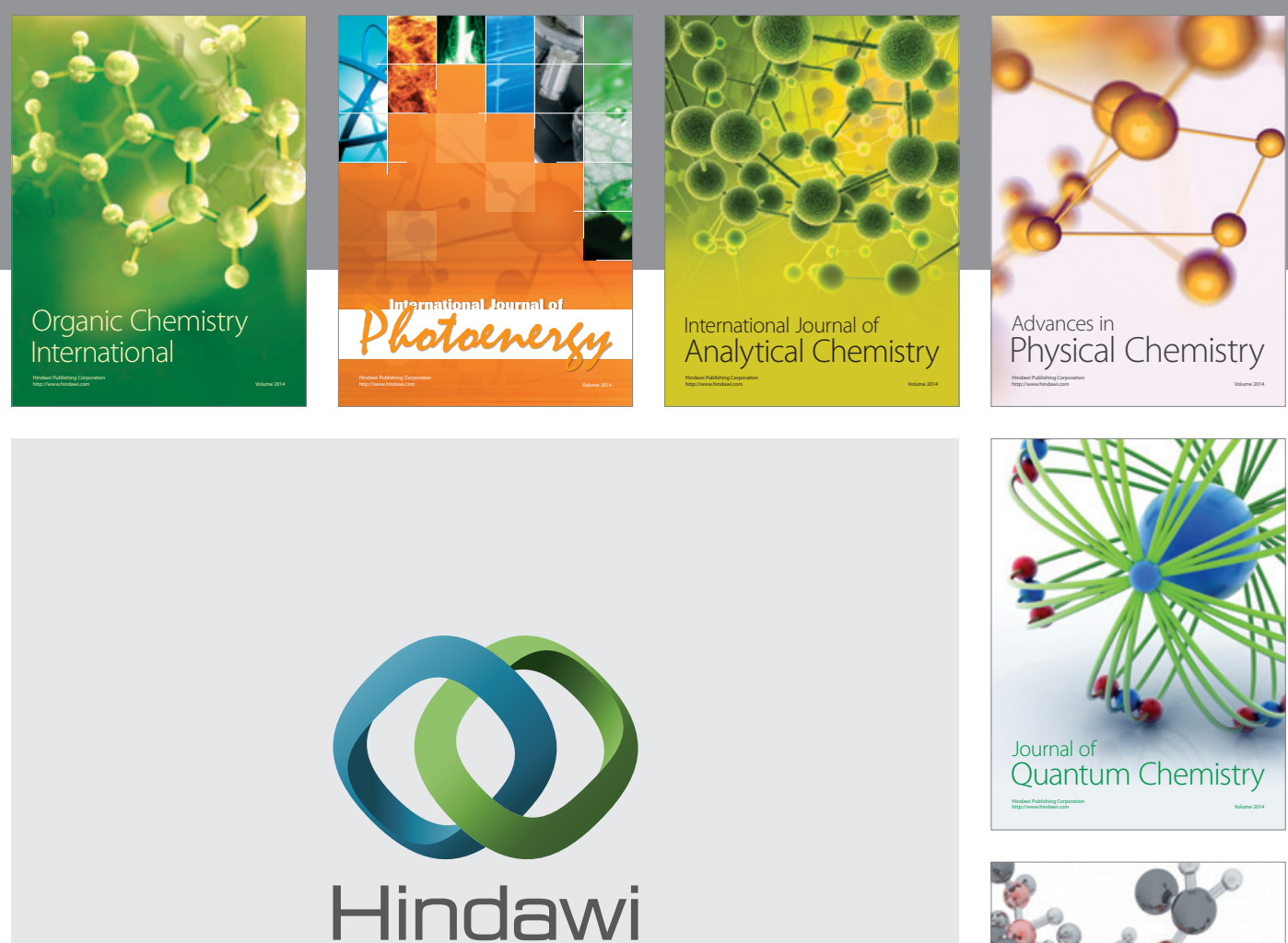

Submit your manuscripts at

http://www.hindawi.com

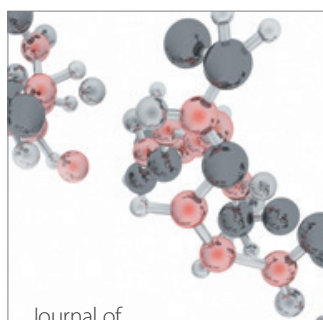

Analytical Methods

in Chemistry

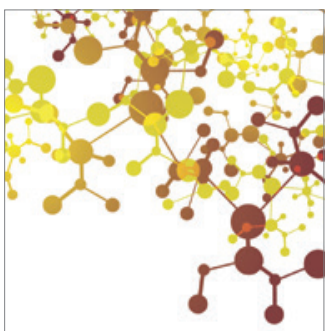

Journal of

Applied Chemistry

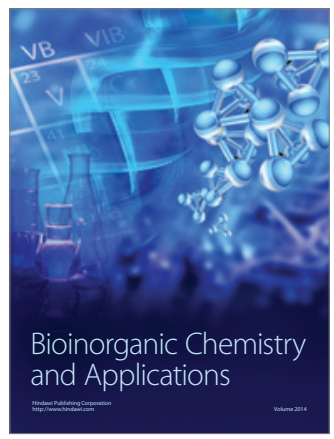

Inorganic Chemistry
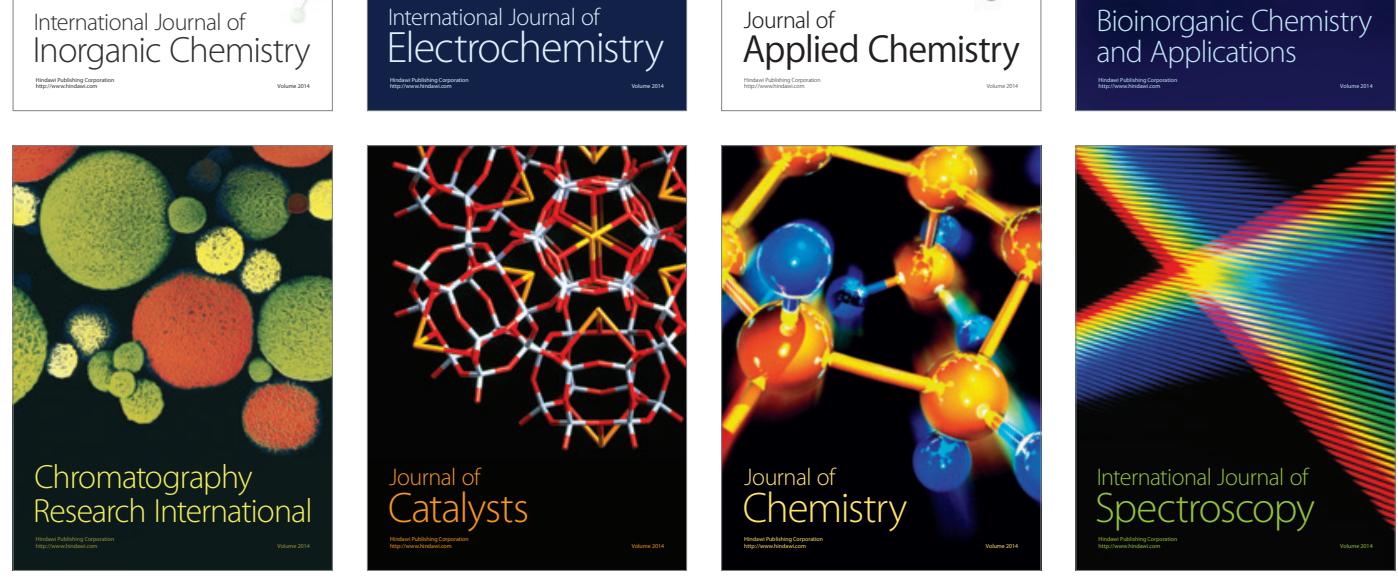